\title{
Felder-Silverman Learning Style Model and the Relationship With Academic Performance
}

\author{
Dyah Lestari Widaningrum and Ho Hwi Chie \\ Industrial Engineering Department, Faculty of Engineering \\ Bina Nusantara University
}

\begin{abstract}
The gap between organizational demands on employee competence and actual employee competence gives new challenges to the education industry to continually increase the readiness of its graduates. Teaching models are developed to produce graduates that are in accordance to the demands of the global competition. However in practice, educational staff often use the same model to all of their students (Blau, 2012), setting aside the importance of congruent concept in an effective pedagogical process (Akin-Little \& Little, 2009). The current study is aimed to test the learning style of university engineering students based on the Felder-Silverman model and its role on academic performance. Results showed that engineering students in this study have the following learning style preferences: ActiveSensing-Visual-Global, which can be used as a base to design teaching methods, which will hopefully be able to provide better support to students' academic performance. Furthermore, a significant relationship between learning style for Active-Reflective dimension and academic performance was found, as indicated by their GPA.
\end{abstract}

Keywords: learning styles, Felder-Silverman, academic performance

Kesenjangan yang terjadi antara tuntutan organisasi terhadap kompetensi yang diharapkan dapat dipenuhi oleh karyawan dengan kompetensi yang dimiliki oleh karyawan, memberikan tantangan baru bagi industri pendidikan untuk terus meningkatkan kesiapan para lulusannya. Model-model pengajaran terus dikembangkan untuk dapat menghasilkan lulusan-lulusan yang selaras dengan tuntutan kompetisi global. Akan tetapi dalam penerapannya, tenaga pendidik seringkali menggunakan model yang sama untuk seluruh anak didiknya (Blau, 2012), mengesampingkan pentingnya konsep yang kongruen dalam proses pedagogi yang efektif (Akin-Little \& Little, 2009). Penelitian ini ditujukan untuk menguji learning styles dari mahasiswa teknik berdasarkan model Felder-Silverman dan peranannya terhadap kinerja akademis. Hasil penelitian menunjukkan bahwa responden yang merupakan mahasiswa Teknik Industri yang menjadi responden dalam penelitian ini memiliki Learning Styles Preferences: Active-Sensing-Visual-Global, yang dapat menjadi dasar untuk mendesain metode pengajaran, sehingga diharapkan ke depannya dapat lebih mendukung kinerja akademis dari mahasiswa. Selain itu juga ditemukan indikasi adanya hubungan yang signifikan antara gaya belajar untuk dimensi Active-Reflective dengan kinerja akademis, dalam hal ini Indeks Prestasi Kumulatif mahasiswa.

Kata kunci: gaya belajar, Felder-Silverman, kinerja akademis

Globalization gives rise to numerous consequences in the working world (Van Dam \& Van den Berg, 2004), which indirectly creates various movements in life paradigms, organizational behavior, and social interactions (Taylor \& Kluemper, 2012; Odle-Dusseau, Britt, \& Greene-Shortridge, 2012). More challenging

Correspondence concerning this article should be addressed to Dyah Lestari Widaningrum, Industrial Engineering Department, Faculty of Engineering, Bina Nusantara University, Jalan KH. Syahdan 9, Jakarta, 11480, Indonesia. E-mail: dwidaningrum@binus.edu competition, for example, demands many multinational organizations to allocate big budgets to train employees in the hopes of increasing competitiveness and maintaining organizational sustainability (Von Glinow \& McShane, 2008).

A gap exists between organizational demands on expected employee competence and actual employee competence. This created new challenges for the education industry to continually increase the readiness of its graduates. Teaching models are always developed 
to produce graduates that meet the demands of global competition; however in practice education staff often uses the same models for each and every student (Blau, 2012). In other words, they set aside the concept that places individual uniqueness in effective pedagogical process (Akin-Little \& Little, 2009).

Felder and Silverman (1988) found a mismatch between the general learning style of university engineering students and traditional learning style of educators in multiple dimensions, that have a negative consequence on students' academic performance and increases frustration on educators. This indirectly has a negative consequence on the society due to the decreased potential of good engineering graduates. This finding inspired other researchers to conduct further studies examining the learning styles of engineering graduates and the relationship with teaching styles and other factors, using several learning styles model, such as Montgomery \& Groat (1998) and Ogot \& Okudan (2006) who conduct comparative study between MBTI Kolb - FSLSM; Graf, Viola, Leo, \& Kinshuk (2007), Kapadia (2008), and Katsioloudis \& Fantz (2012) who were using FSLSM; Hargrove, Wheatland, Ding, \& Brown (2008) and Cagiltay (2008) who were using Kolb model; and Lee \& Sidhu (2013) who were using Honey and Mumford Learning Styles; and they were underlining the need to study the learning style of students and to try to match it with the educator's teaching style.

The Biglan model is the most well-known scheme of classifying cognition-based scientific disciplines. This model classifies disciplines into three dimensions: hard/soft, pure/applied, and life/non-life system (Alise, 2008; Sinclair \& Muffo, 2002). In this classification, industrial system engineering is classified as "hard discipline - applied - non-life system" (Sinclair $\&$ Muffo, 2002).

Studies by Neumann (2001) and Laird and Garver (2008) showed an indication that the approach taken by educators in their teaching is affected by their scientific discipline. Neumann (2001) explained that an interaction between student learning and differences in scientific discipline is important to be considered to obtain good quality teaching and learning. Referring to Biglan's classification, engineering education needs the ability to memorize and apply class materials to develop problem-solving competence. Thus, it can be understood that research and learning styles are important to be done specifically for each classification of scientific disciplines, so that the teaching system is designed not only by considering students' learning styles but also the characteristics of said scientific discipline.
Each individual, just like students, are unique in a sense that they differ from one another. Each has different responses on the instructional environment, and differing motivation and preferences (Felder \& Brent, 2005). Felder and Silverman (1988) categorize learning styles into four dimensions: sensing, visual, active, and sequential. Thus, how significant is the correlation between engineering students' learning style and their academic performance?

Some studies showed that academic performance is affected by the teaching style of educators (Felder \& Spurlin, 2005; Dyer \& Osborne, 1999; Garton, Spain, Lamberson, \& Spiers, 1999; Dever \& Kara-benick, 2011). Felder and Silverman (1988) explained the various ways a student learns, by watching and listening; by reflecting and acting; by memorizing and visualizing and drawing analogies and constructing mathematical models.

Teaching methods also vary, with lecturing or discussing or demonstrating; some focus on the principle of a concept, while others focus on the application of those concepts; some stresses memorization while others prioritize understanding. Felder (1993) explained numerous methods of teaching in class that was hoped to be sufficient and appropriate to the needs of students, and suggested to discuss the learning styles of students in class or even when advising. In 1995 and 1998 (Felder, 1995; R. M. Felder, Felder, \& Dietz; 1998a; R.M. Felder, Felder, \& Dietz; 1998b), it was explained further the relationship between learning styles with performance and retention of engineering students. Felder and Silverman (1988) further constructed the Index of Learning Styles (ILS) which was a selfscoring web-based instrument measuring preferences on the dimensions Sensing/Intuiting, Visual/Verbal, Active/Reflective, and Sequential/Global.

Felder and Spurlin (2005) stated that the Index of Learning Styles (ILS) have two main uses, as a guide for educators related to the variety of student learning styles as well as an aid to design teaching methods based on the overall learning style of students. The second use is to provide information to students as individuals regarding the benefits and disadvantages of their learning style.

Garton, Spain, Lamberson, and Spiers (1999) provided evidence that there is a positive relationship between learning style and academic achievement of students, as well as a relationship between teaching performance and one particular learning style. Demirbas and Demirkan (2007) conducted a study that was focused on the design of teaching methods using experiential learning theory (ELT) and exploring 
the effects of learning styles and gender on three cohorts of design students' performance scores. Hargrove et al., (2008) investigated the relationship between individual learning styles and their effects on academic achievement, in this case the GPA scores of engineering students.

The competition of educational institution organizations are viewed as an effort that can yield material benefits. As a consequence, the operational processes of educational institutions instead closely mirror business models prioritizing effectiveness and efficiency. On the other hand, lecturers are faced with learning demands that enables students to develop according to their own capacity. Understanding learning styles is thus important especially in the process of learning of engineering sciences.

The concept of learning style by Felder and Silverman has been tested in various developed countries. Crosscultural differences, however, gave rise to questions about whether this concept can be applied in Indonesia, specifically in engineering education. The aim of this study was to test the learning style of civil engineering students based on Felder and Silverman's concept in its correlation with general academic performance.

Sinclair and Muffo (2002) classify civil engineering as a Hard Skill/Applied/Non-Life System along with other engineering sciences (Civil Engineering, Engineering Science \& Mechanics, Mechanical Engineering, Minerals \& Mining Engineering, Material Science Engineering, Aerospace \& Ocean Engineering). However, at its core, civil engineering has special characteristics, which enables industrial engineers to work in various business types, while other engineering disciplines only allow their graduates to apply their skills on very specific areas (source: Institute of Industrial Engineers). As such, it would be interesting to study the learning style preferences of civil engineering students and its relationship with academic performance.

\section{Method}

Civil engineering is a scientific discipline categorized in Hard Skill/Applied/Non-Life System (Sinclair $\&$ Muffo, 2002) and is thus considered appropriate to be studied in this research. A total of 103 civil engineering students (the 2013 cohort) from a top-rank private university in Jakarta were recruited as a sample.

Test of learning style from each student was done using the Index of Learning Styles Questionnaire from Solomon and Felder consisting of 44 items, separa- ted into four dimensions, as explained by Felder and Silverman (1988) as follows:

1. What information type is preferred by student:

Sensory (vision, hearing, physical sensation)

Intuitive (possibility, insight, estimates)

2. From which sensory media does external information accepted effectively:

Visual (pictures, diagrams, graphs, demonstrations)

Verbal (words, voices)

3. Which information processing activity is preferred by the student:

Actively (active physical involvement or discussion)

Reflectively (through introspection)

4. How is the advancement of understanding of students:

Sequential (gradually)

Global (holistically, in a huge 'leap')

Cronbach's alpha reliability coefficient with a minimum score of .5 as a criteria of ILS is accepted, as explained by Tuckman (cited in Felder \& Spurlin, 2005) that an alpha value of .5 or more is acceptable for attitude assessment. Reliability test results for each dimension are presented in Table 1.

The reliability test results have a similar pattern with the reliability test of ILS model from Felder and Silverman, done by Litzinger, Lee, Wise, \& Felder (2007), which came from four studies (with Ns between 242 - 557), the Active-Reflective dimension had a value between $.51-.61$; Sensing-Intuitive between .65 - .77; Visual-Verbal between .56 - .76; and SequentialGlobal between $.41-.55$.

A total of 103 students were asked to fill out sheets of questionnaire in the classroom they usually attend for on-campus learning activities. Due to space constraints, data collection was split in two stages. For the questionnaire, students were asked to choose between the two options that they feel most appropriate with their view, as seen in Table 2 . To avoid bias due to English language ability, a translation of the questionnaire was provided. The instrument used is a web based questionnaire (Index of Learning Styles). The next step was inputting questionnaire results to the link.

The academic performance variable which will be examined with its relationship to learning style of students were seen from respondents' GPA. GPA data were obtained from faculty information to ensure data accuracy. GPA used was cumulative GPA in the second semester, as seen in Table 3.

Data of semester 1, semester 2, and cumulative GPA showed a normal distribution, with a significance value of greater than .15 among the three variables (significant). The normal probability plot was shown in Figure 1. 
Table 1

$\begin{aligned} & \text { Cronbach's Alpha Coefficient From Index of } \\
& \text { Learning Styles }\end{aligned}$
\begin{tabular}{lcc} 
Instrument & $\begin{array}{c}\text { Cronbach's } \\
\text { Alpha }\end{array}$ & $\begin{array}{c}\text { Corrected Item- } \\
\text { Total Correlation } \\
\text { span }\end{array}$ \\
\hline Active - Reflective & .466 & $-.036-.331$ \\
Sensing - Intuitive & .541 & $.010-.324$ \\
Visual - Verbal & .696 & $.093-.615$ \\
Sequential - Global & .418 & $.051-.281$
\end{tabular}

Table 2

\section{Example ILS Questions for Each Dimensions}

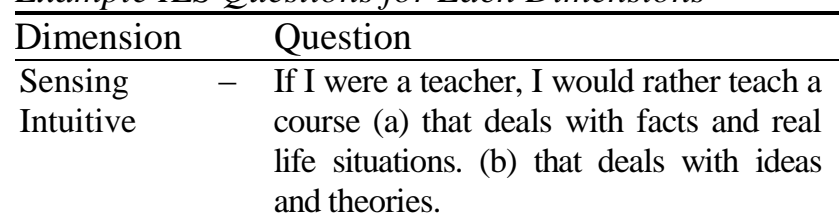

Visual - When someone is showing me data, I Verbal prefer (a) charts or graphs. (b) text summarizing the results.

Sequential - When I am learning a new subject, I Global prefer to (a) stay focused on that subject, learning as much about it as I can. (b) try to make connections between that subject and related subjects

Active $\quad-$ I am more likely to be considered (a) Reflective outgoing. (b) reserved.

Table 3

Descriptive Analysis of Students' GPA

\begin{tabular}{lc}
\hline Statistics & Cumulative GPA \\
\hline Mean & 2.70 \\
Standard Deviation & 0.61 \\
Minimum & 1.50 \\
Maximum & 4.00 \\
\hline
\end{tabular}

A multiple regressions analysis (using SPSS) was done to examine whether there was a significant relationship between learning style and academic performance. In addition, descriptive analysis was done to determine learning styles based on test results.

\section{Results and Discussion}

The Felder-Solomon Index of Learning Styles (ILS) consisting of 44 questions across four dimensions was used to identify learning style preferences referring to Felder and Silverman Learning Style Model
(FSLSM) expressed with values of -11 to +11 (odd values only) to each dimension (see Figure 2.)

The four dimensions depicted were Learning Styles Result consisting of the following dimensions: Active-Reflective, Sensing-Intuitive, Visual-Verbal, and Sequential-Global. Each dimension has a twodirectional scale, 1 - 11 (odd values only) where the test result position will be shown by a cross mark on a score in one direction of the scale. If a participant earned a score between 1 or 3 then the person will be scored as having a balance towards the two dimensions; when a participant earns a score of 5 or 7 then the individual will be deemed as having a moderate preference for one side of the dimension, and if they earn a score of 9 to 11 then the individual will be deemed as having an extreme preference on one side of the dimension, indicating that the person will face difficulties adopting an opposing learning style.

As an example, as seen in Figure 2, XXX was shown to have a balanced preference for the dimension Active-Reflective and Sensing-Intuitive, so that any learning style from these two dimensions could be accepted relatively well for the individual. For Sequential-Global, the individual possessed a preference for sequential learning style, and thus will have an easier time to learn when placed in a learning environment that accommodates this particular style. For Visual-Verbal dimension, the individual had an extreme preference to the visual learning style, and so it can be said that the individual will have a difficult time learning in an environment that does not support the particular learning style.

For ease of interpretation, scores on the ILS FelderSolomon was frequency categorized: for scores of 1 and 3 on the dimension, the score will be categoryzed as a balanced learning style. Scores of 5 and 7 for each side of the dimension were clustered as a group that will be more successful when supported with a particular learning style on the preferred dimension. Scores of 9 and 11 for each side of the dimension was grouped as those who will face difficulties when inadequate support was given to the preferred learning style.

The ILS distribution for active-reflective dimension (see Figure 3) showed that $49 \%$ of the respondents have a balanced learning style for each side, which means that students are relatively capable of accepting a learning environment that supports either active or reflective style, while $37 \%$ will be more successful if the environment supports an active style, and $11 \%$ will struggle when the environment forces 


\section{Normality Test - GPA}

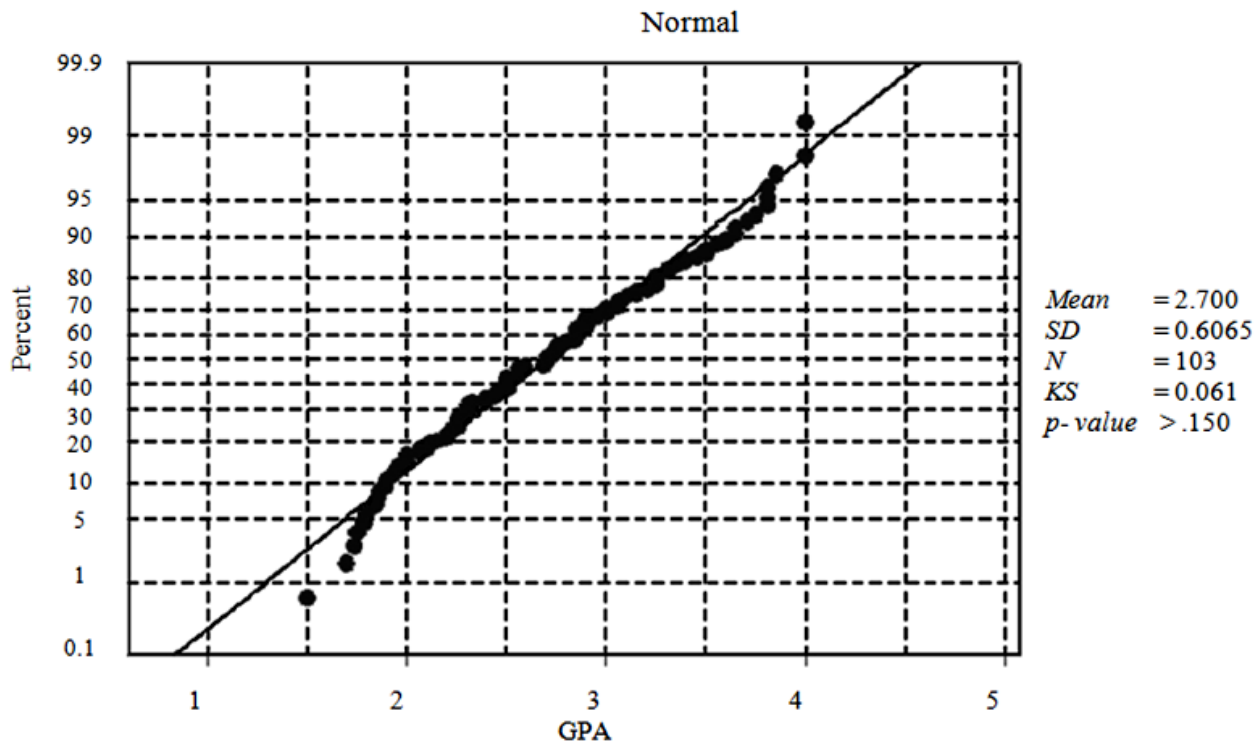

Figure 1. Normal probability plot of students' GPA $(N=103)$.

Learning Styles Scales

NC STATE UNIVERSITY http://engr.ncsu.edu/learningstyles/submit.php

\section{Learning Styles Results}

Results for: $\mathrm{XXX}$

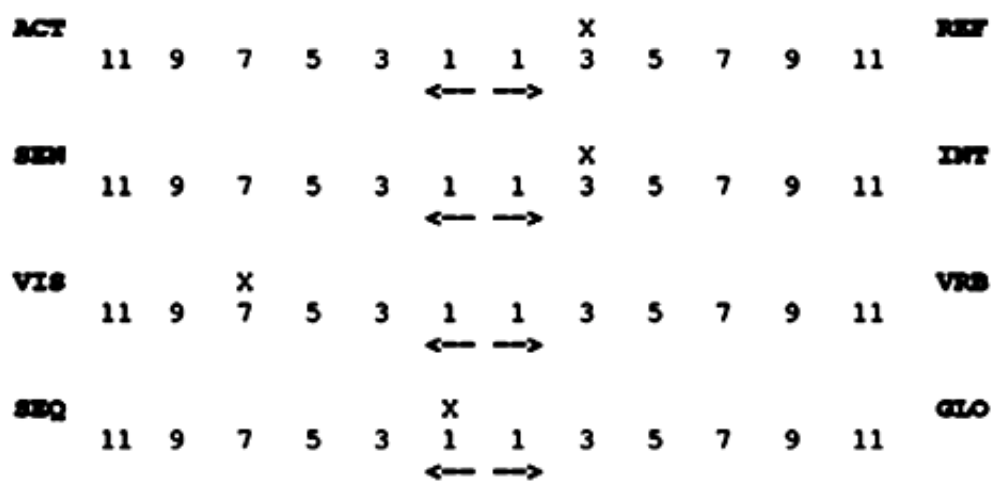

Figure 2. Learning style result from the Felder-Solomon ILS (example).

them to study reflectively. In other words, $96 \%$ of students are able to accept an active learning style, while only $52 \%$ can accept reflective learning style. An example of a teaching style that supports an active learning style is giving materials that highlight practice of problem solving methods and giving an opportunity to students to be actively involved in the learning process, such as giving a five minutes group discussion (Felder \& Silverman, 1988).

ILS distribution for Sensing-Intuitive dimension (see Figure 4), showed that half of the respondents $(46 \%)$ had a balanced learning style for both sides. They were relatively capable of being placed in an environment that supports either sensory or intuitive 
DIMENSION: ACTIVE - REFLECTIVE

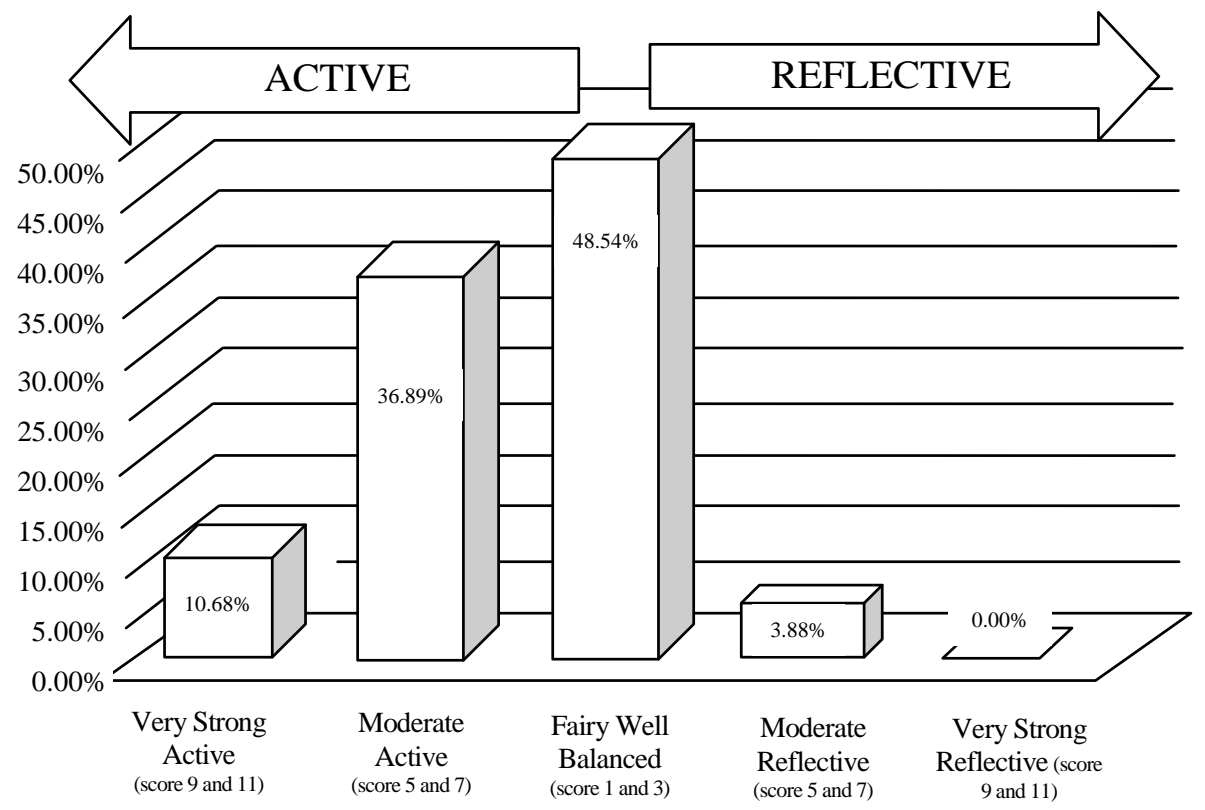

Figure 3. ILS Distribution for active-reflective dimension $(N=103)$.

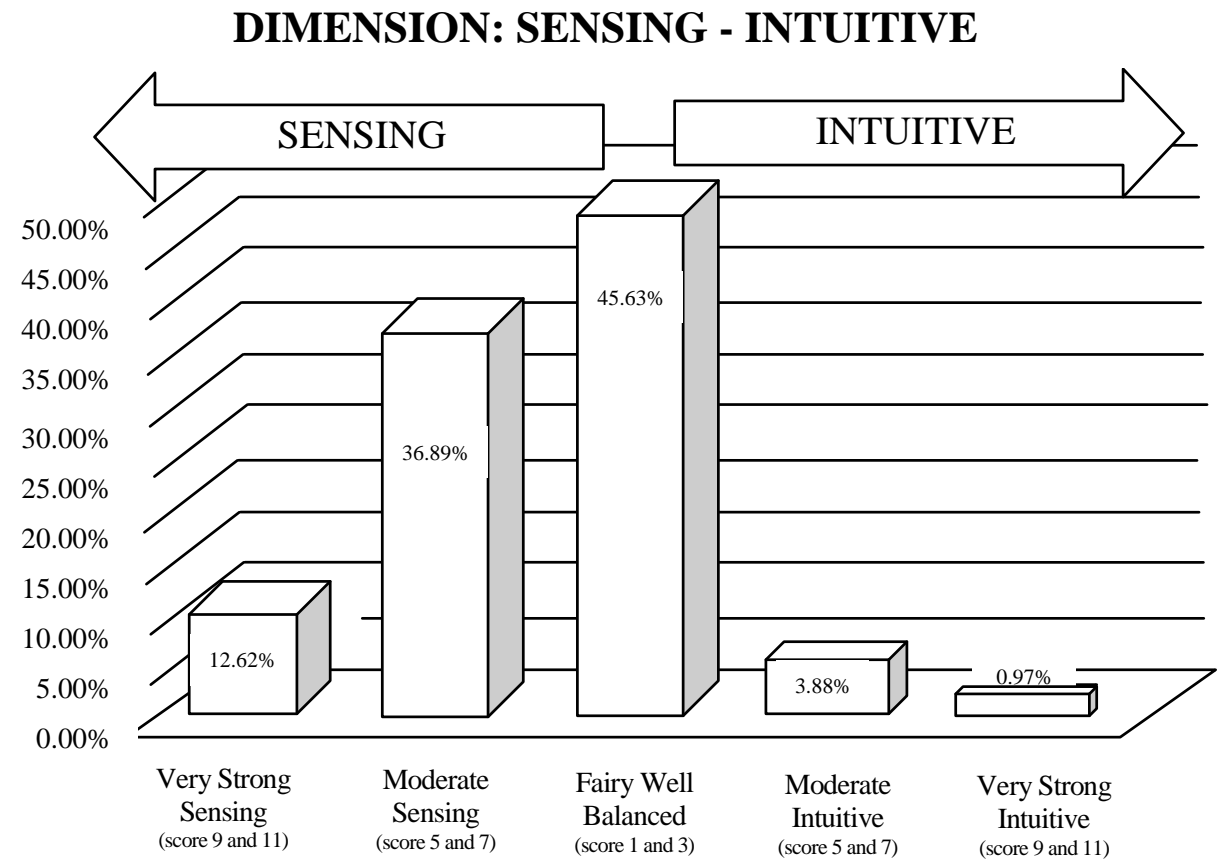

Figure 4. ILS Distribution for sensing-intuitive dimensions $(N=103)$.

learning style. On the other hand, $37 \%$ will be more successful if placed in an environment that supports sensory learning style, and $13 \%$ will struggle on an environment that only supports intuitive learning style. Therefore, $95 \%$ of students are able to accept a sensory learning style environment, while only $50 \%$ are able to be placed in an intuitive style environment. An example of a sensory learning style in- 
clude providing concrete information (facts, data, real or hypothetical experiments and the results) and providing computer-assisted instructional exercises during practice sessions (Felder \& Silverman, 1988).

Figure 5 shows ILS distribution for Visual-Verbal dimension, student preference tends to cluster in one dimension, which is visual. Only $27 \%$ was found to have a balanced learning style on both Visual -
Verbal sides, $3 \%$ will be more successful when supported for a verbal learning style, $1 \%$ will struggle when inadequate support was provided for verbal learning style. This meant that only $31 \%$ of student is able to accept verbal learning style, while $96 \%$ are able to accept a visual learning style environment.

Of particular note, a number of students had extreme preference to visual learning style (38\%). As

\section{DIMENSION: VISUAL - VERBAL}

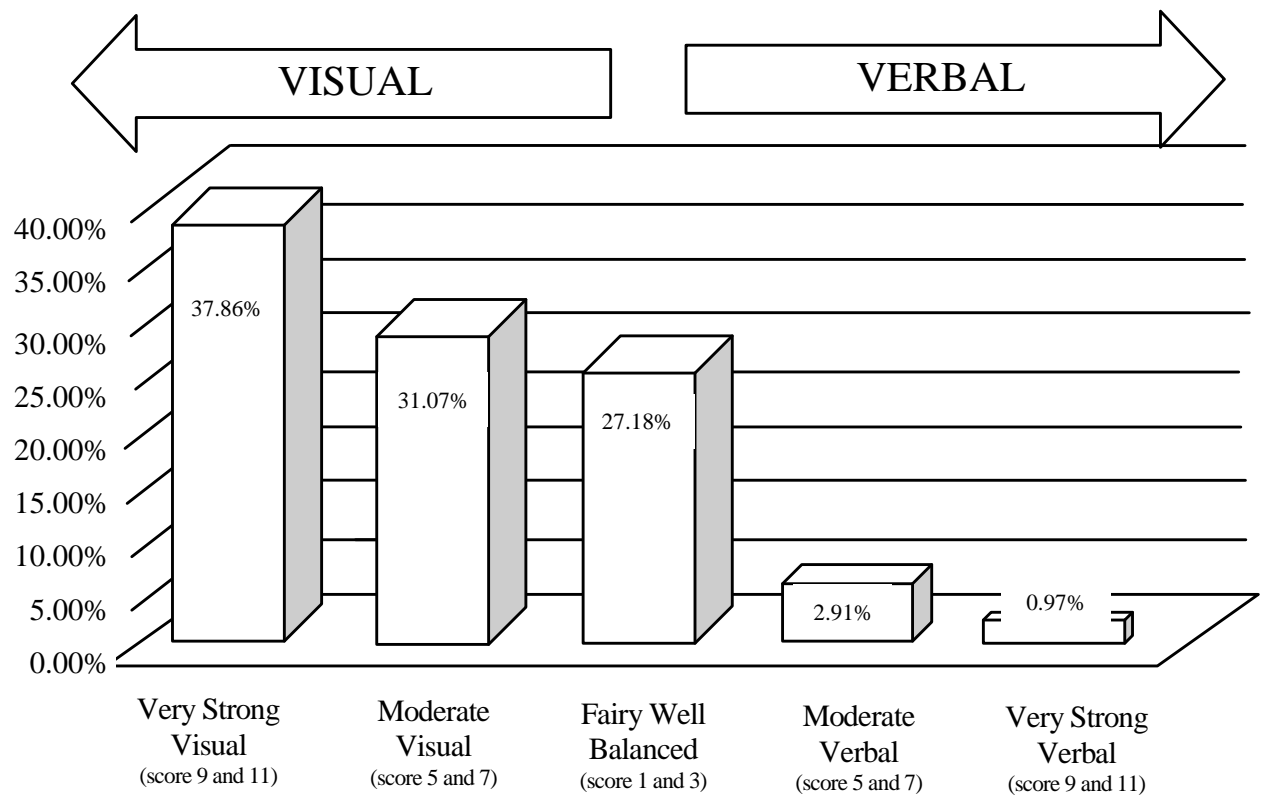

Figure 5. ILS Distribution for visual-verbal dimension $(N=103)$.

\section{DIMENSION: SEQUENTIAL - GLOBAL}

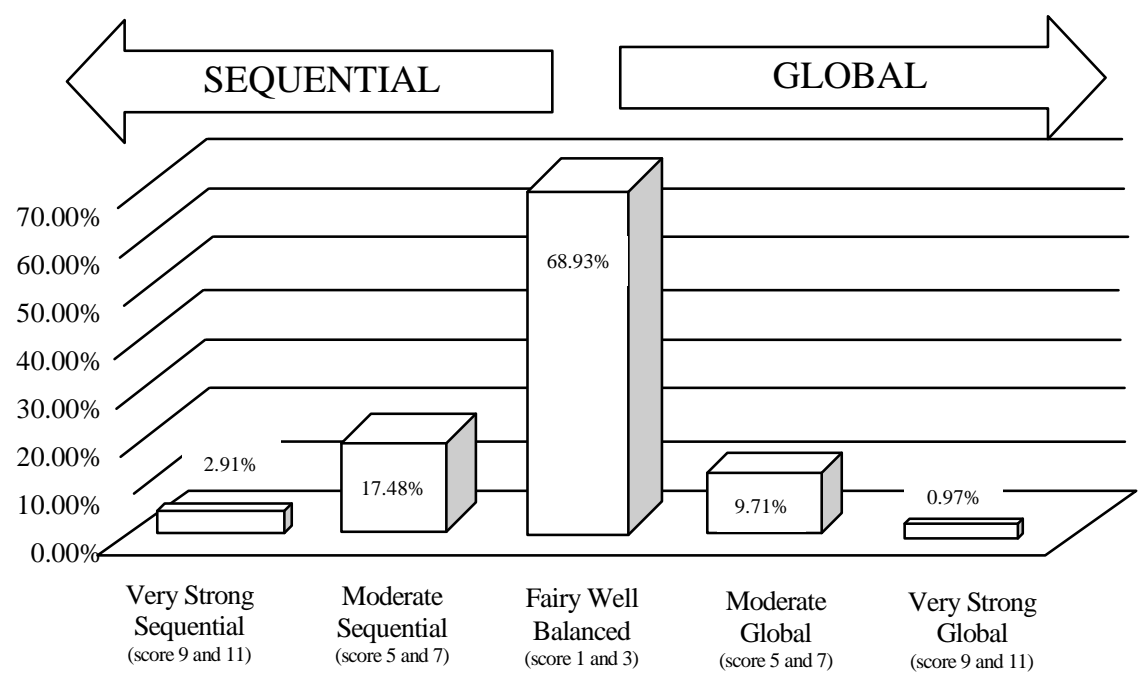

Figure 6. ILS Distribution for sequential-global dimension $(N=103)$. 
seen in Figure 2, ILS Felder-Solomon output pointed that when one had a score supports a verbal learning style. One way to support a verbal learning style is to use pictures, schemas, graphics, sketches - before, during, and after verbal presentation of learning materials (Felder \& Silverman, 1988).

Unlike the frequency distribution of the three pre- vious dimensions, on the Sequential-Global dimension, $69 \%$ respondents had a balanced learning style on each side of the dimensions (see Figure 6). There was only a $10 \%$ difference on students who accept only one dimension, $90 \%$ are accepting an environment designed for sequential learning style, and $80 \%$ are accepting a global learning style environment,

Histogram: Cumulative GPA

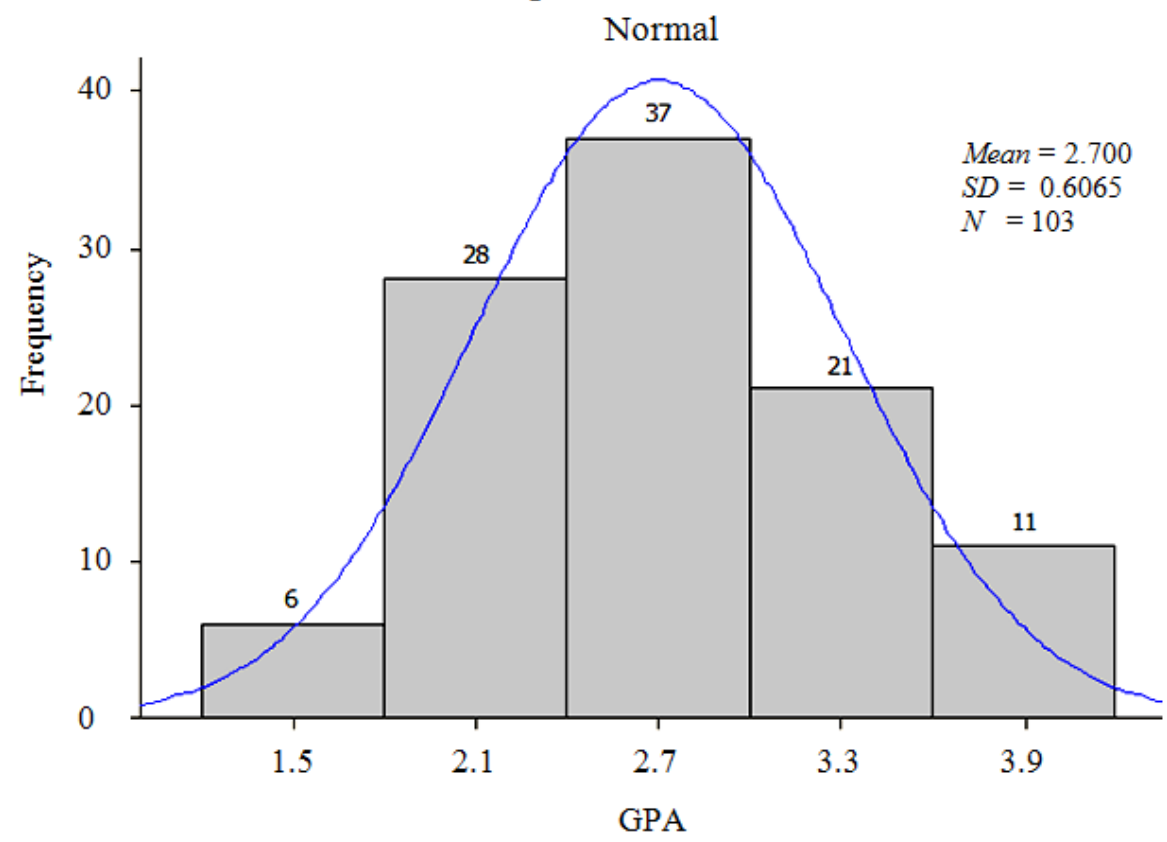

Figure 7. Distribution of students' cumulative GPA Score $(N=103)$.

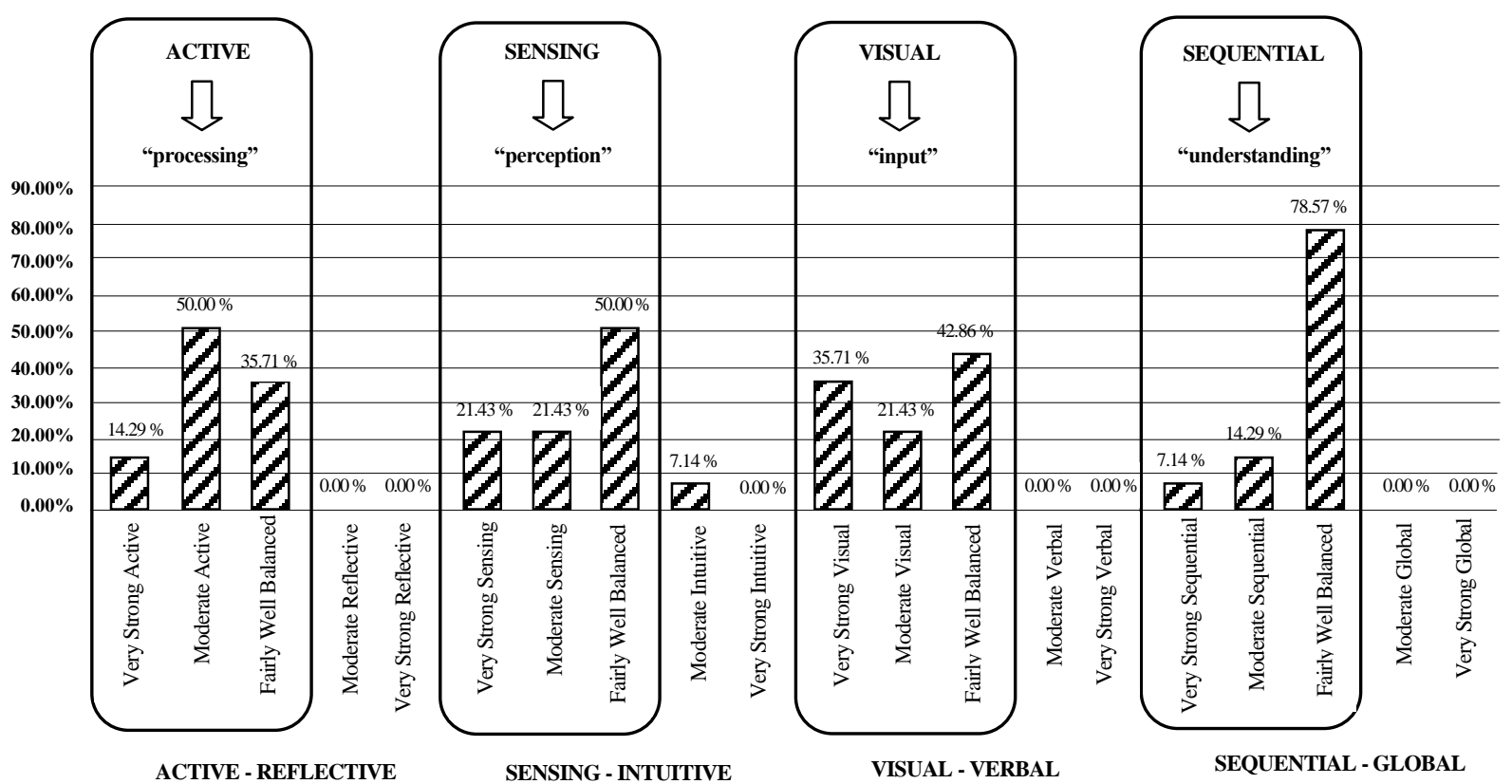

Figure 8. Learning style preferences of respondents with a GPA of $1.50-1.99(N=14)$. 


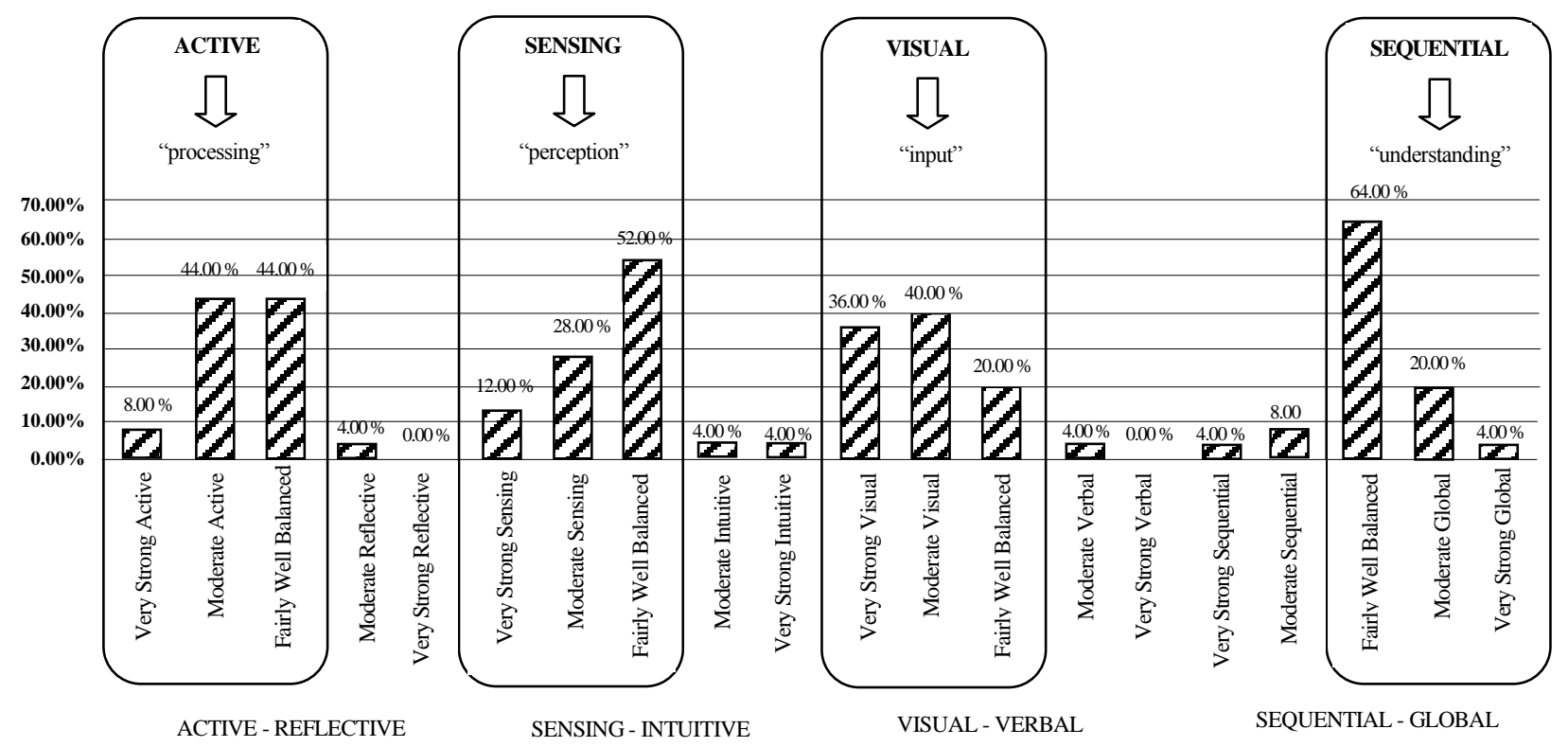

Figure 9. Learning style preferences of respondents with a GPA of $2.00-2.49(N=25)$.

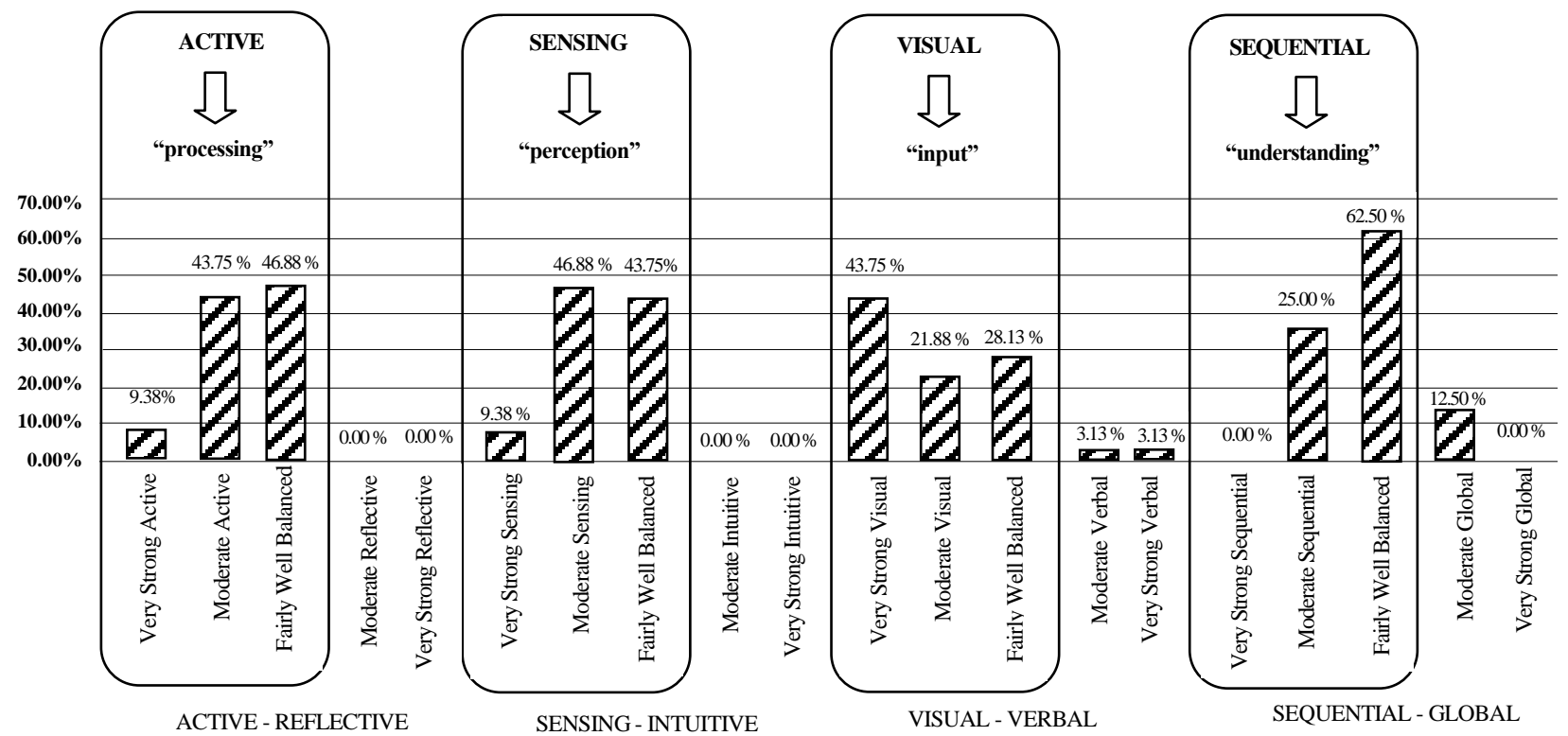

Figure 10. Learning style preferences of respondents with a GPA of $2.50-2.99(N=32)$.

and $1 \%$ will struggle when forced to adopt a sequential learning style. A balanced learning style for this dimension as well as a small percentage of respondents with extreme learning preference is beneficial as this means that students can focus more on the concepts of the learning material.

Academic performance and its relationship with learning style are observed through students' GPA.
Statistical analysis showed that there was no evidence to show that semester 1 GPA had a significantly different data characteristic from semester $2 \mathrm{GPA}(p$-value $=.401)$, with a mean/SD scores of $2.66 / 0.69$ for semester 1 GPA and 2.58/0.74 for the second semester. Therefore, for the next analysis the cumulative GPA will be used, with a mean of 2.70. A standard deviation score of .61 and a range of 2.50 showed a GPA distribution 
that is quite spread, indicating a variety of academic performance (see Figure 7). If students in this study was categorized based on the range of GPA as shown in the histogram in Figure 7, then the Learning Styles Model of Felder and Silverman for each GPA group are reflected in Figures 8, 9, 10, 11, and 12.

Comparing the learning style preferences of students across five GPA categorization groups in Figures 8, $9,10,11,12$, it can be concluded that four of the groups have learning style preferences model from Felder and Silverman that are in line with the total learning style preferences of respondents, except for the group with a GPA between $2.00-2.49$, in particular the Sequential-Global dimension, $88 \%$ of the respondents (out of 25) were able to accept a learning environment that supports global (holistic) style of learning. Thus, for Sequential-Global dimension, a combination of good learning environment supporting sequential and global learning styles are needed, not only tailored to fit with the learning materials but also adjusted with student characteristics that are more varied in this dimension. An example would be to combine sequen-

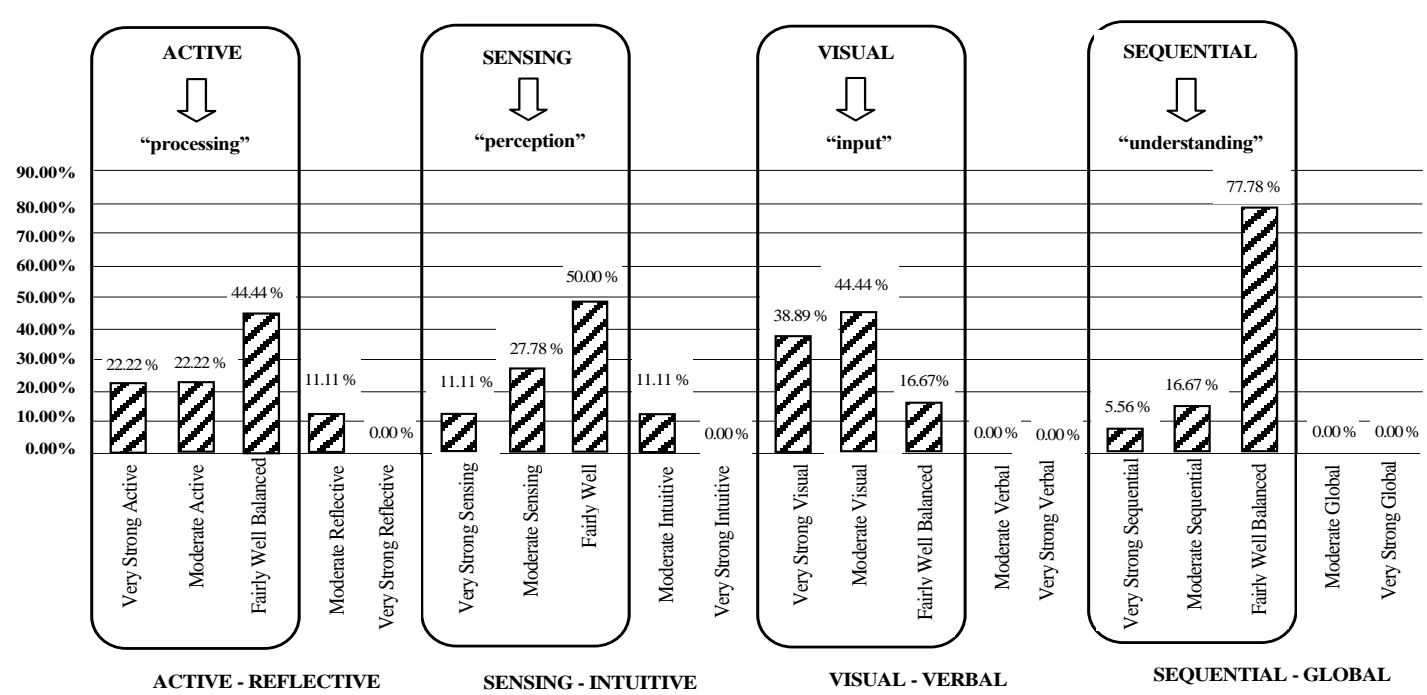

Figure 11. Learning style preferences of respondents with a GPA of $3.00-3.49(N=18)$.

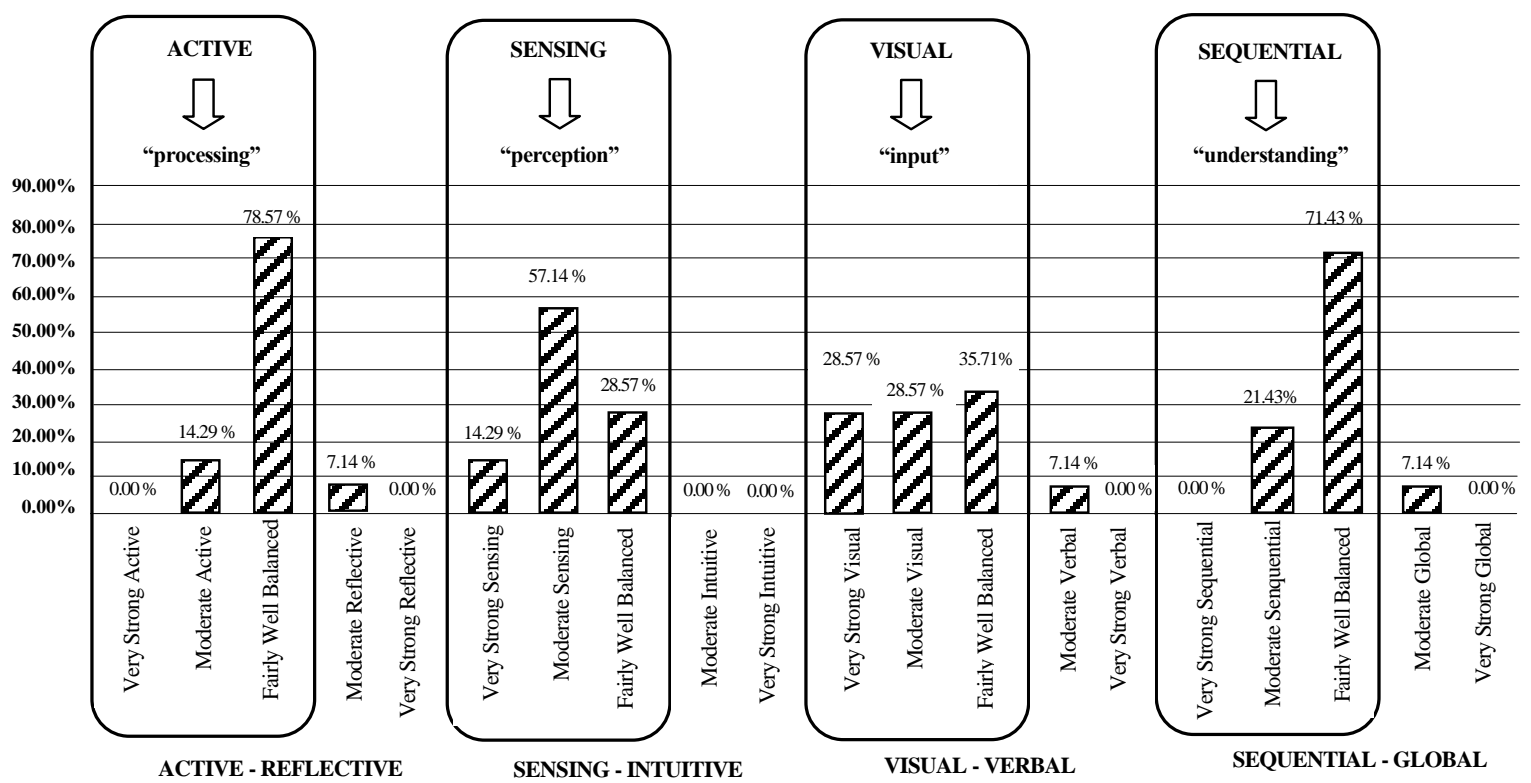

Figure 12. Learning style preferences of respondents with a GPA of $3.50-4.00(N=14)$. 
tial teaching style that explains the order of a process and the consequences of a theory, with a global teaching style that sometimes provide theories or concepts.

To analyze the relationship between GPA as a function of academic achievement with the learning styles model from Felder and Silverman, a multiple linear regression method was conducted using SPSS with GPA as a dependent variable and four dimensions of learning styles model from Felder and Silverman as independent variables. Graphical analysis with scatterplot revealed a linear pattern between the dependent variable and the independent variables, and through normal probability plot it can be concluded that the data is normally distributed (met the assumptions). Result of significance testing on the independent variable affecting the dependent variable, with a $p$-value of .028 that is less than the $\alpha$ of $5 \%$, showed that the learning style variable "Active-Reflective" had a significant effect on GPA, whereas the other three independent variables were not shown to have any effect on GPA $(p>.05)$. Results are presented in Table 4.

Learning Styles model index from Felder and Silverman in the Active-Reflective dimension is shown to have a significant relationship with academic achievement. The more reflective a student's learning style is, the greater their GPA will be. This result can explain the finding by Felder and Silverman (1988) for this dimension; a majority of engineering students have an active learning style, however the teaching style of the lecturers does not accommodate the particular learning style and this resulted in bad student performance and increasing frustration of lecturers. Related to this study, it is suspected that lecturers' learning style forces students to become passive listeners, and as such only students with a reflective learning style will benefit from this, because they have the time and space to think back on the information provided by the lecturer and are more comfortable to study individually (indirectly resulting in better GPA scores). This is further strengthened by the university curriculum structure on engineering students' first year courses that focuses on basic science such as physics, calculus, and chemistry. This further encourages lecturers to adopt a more traditional teaching style.

Felder and Silverman (1988) explained that active and reflective teaching styles are equally necessary for potential engineers. Moreover, it was explained that educators need to organize learning situations that can be accepted by students with either active or reflective learning styles, such as by giving time to think (reflect) with discussion or with a problem-solving activity (active) (Felder \& Silverman, 1988).

The learning style of the engineering faculty represented by second semester civil engineering students, according to the Index of Learning Styles model by Felder-Silverman generally categorized as Active-SensingVisual-Sequential. They tend to prefer involvement in physical activity or discussions (Active); find it easier to construct an understanding based on what they see, hear, and physically sense (Sensing); prefer to receive information in the form of pictures, diagrams, graphics, and demonstrations (Visual); as well as understanding things in a gradual manner (Sequential). Statistically, the data showed a significant positive correlation between indexes of learning style for the Active dimension with academic achievement indicated by cumulative GPA on the second semester. Clustered into five groups depending on their GPA range, it shows that one group stood out, having a global learning style, whereas four others have a sequential learning style.

\section{Limitations and Suggestions}

The current research is a preliminary study that can be followed up with designing a teaching method to develop a learning environment that supports various learning style preferences. Limitations of the current

Table 4

Descriptive Analysis of Students' GPA

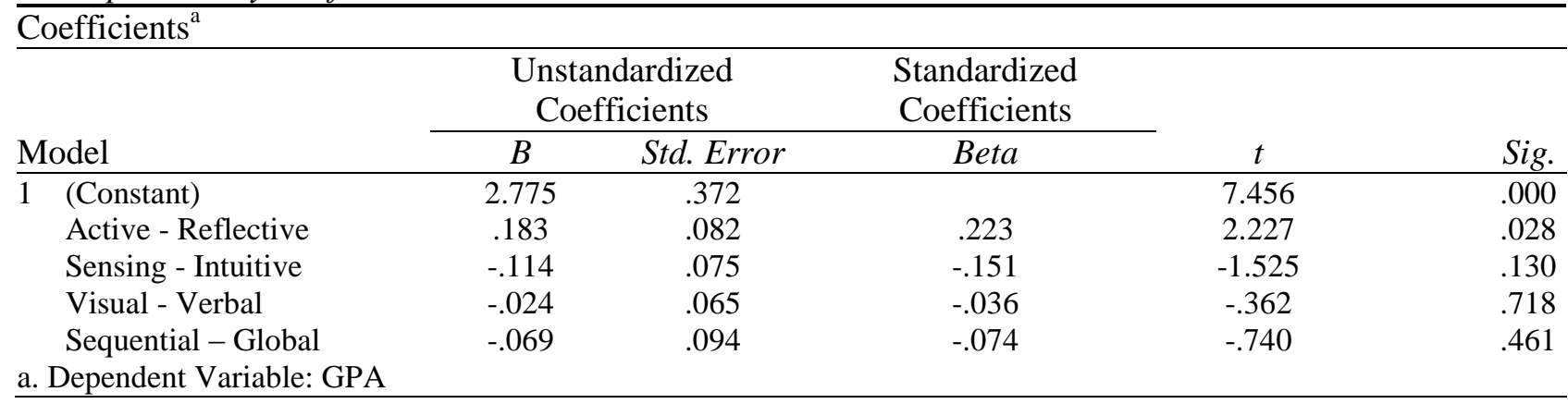


study include a low reliability score, lower than .5 for two dimensions, whereas in the current study a new measurement tool was not developed because of the usage of a web based instrument. It was also possible that the sample size and variation affect the results of the study, and thus there is still an opportunity to develop the study longitudinally or comparatively with other disciplines to obtain more specific information. For example, the relationship between the increase of GPA and student retention with a combination of learning and teaching styles, the relationship between learning design and student learning style, or other variables affecting learning styles, academic performance, and student retention, all with the aim to provide support for students to achieve the goals of the program educational objectives).

\section{Conclusion}

This finding is important for lecturers and academicians, particularly suggesting them to note the learning style preference for Active-Reflective dimension and the correspondence with teaching style, so that the educational environment can be adjusted to support students' academic performance. Teaching methods need to be balanced on these two categories, the global learning style, and the sequential learning style, where students are not only provided detailed step-by-step understanding, but also a holistic approach relating the given materials with other theories/concepts as well as the aim of the concept (focusing on the relevance of the learning materials).

\section{References}

Akin-Little, A., \& Little, S. (2009). The true effects of extrinsic reinforcement on "intrinsic" motivation. In A. Akin-Little, S. Little, M. Bray, \& T. Kehle (Eds.), Behavioral interventions in schools: Evidencebased positive strategies (pp. 73-91). Washington, DC: American Psychological Association.

Alise, M. A. (2008). Disciplinary differences in preferred research methods: A comparison of groups in the Biglan classification scheme (Unpublished Doctoral Dissertation), Lousiana State University, Bouton Rouge, LA.

Blau, D. (2012). Who leads the classroom? Society for Humanistic Psychology Newsletter, April.

Cagiltay, N. E. (2008). Using learning styles theory in engineering education. European Journal of Engineering Education, 33(4), 415-424.
Demirbas, O. O., \& Demirkan, H. (2007). Learning styles of design students and the relationship of academic performance and gender in design education. Elsevier Learning and Instruction, 17, 345-359.

Dever, B., \& Karabenick, S. (2011). Is authoritative teaching beneficial for all students? A multi-level model of the effects of teaching style on interest and achievement. School Psychology Quarterly, 26(2), 131-144.

Dyer, J., \& Osborne, E. (1999). Effects of students learning styles on short and long term retention of subject matter using various teaching approaches. Journal of Agricultural Education, 40(2), 11-18.

Felder, R. M. (1993). Reaching the second tier: Learning and teaching styles in college science education. J. College Science Teaching, 23(5), 286-290.

Felder, R. M. (1995). A longitudinal study of engineering student performance and retention, instructional methods and student responses to them. Journal of Engineering Education, 84(4), 361-367.

Felder, R. M., \& Brent, R. (2005). Understanding student differences. Journal of Engineering Education, 94(1), 57-72.

Felder, R. M., Felder, G. N., \& Dietz, J. E. (1998 a). A longitudinal study of engineering student performance and retention, comparison with traditionally-taught students. Journal of Engineering Education, 87(4), 469-480.

Felder, R. M., Felder, G. N., \& Dietz, J. E. (1998 b). A Longitudinal study of engineering student performance and retention, comparison with traditionally-taught students. Journal of Engineering Education, 91(1), 3-17.

Felder, R. M., \& Silverman, L. K. (1988). Learning and teaching styles in engineering education. Journal of Engineering Education, 78(7), 674-681.

Felder, R. M., \& Spurlin, J. (2005). Applications, reliability, and validity of the index learning styles. Journal of Engineering Education, 21(1), 103-112.

Garton, B., Spain, J., Lamberson, W., \& Spiers, D. (1999). Learning styles, teaching performance, and student achievement: A relational study. Journal of Agricultural Education, 40(3), 11-20.

Graf, S., Viola, S. R., Kinshuk \& Leo, T. (2007). Indepth analysis of the Felder-Silverman learning style dimensions. Journal of Research on Technology in Education, 40(1), 79-93.

Hargrove, S., Wheatland, J., Ding, D., \& Brown, C. (2008). The effect of individual learning styles on students GPA in engineering education at Morgan State University. Journal of STEM Education, 9 (3-4), 37-42. 
Felder, R. M. \& Silverman, L. K. (n.d.) Index of learning styles. North Carolina State University. Retrieved from http://www.ncsu.edu/felder-public/ ILS page.html

Kapadia, R. J. (2008). Teaching and learning styles in engineering education. 38th ASEE/IEEE Frontiers in Education Conference (pp. T4B1T4B4). New York: IEEE.

Katsioloudis, P., \& Fantz, T. (2012). A comparative analysis of preferred learning and teaching styles for engineering, industrial and technology education students and faculty. The Journal of Technology Education, 23(2), 61-69.

Laird, T. F. N., \&. Garver, A. K. (2008). The effect of teaching general education courses on deep approaches to learning: How disciplinary context matters. Received: 24 September 2008/Published online: 17 November 2009. Springer Science+ BusinessMedia, LLC 2009. Research in Higher Education (2010) 51, 248-265. DOI 10.1007/s11162 -009-9154-7

Lee, C. K., \& Sidhu, M. S. (2013). Engineering students learning styles preferences using Honey and Mumford Learning Styles Questionnaire: A case study in Malaysia. International Journal of Information Technology \& Computer Science, 107-114. Bangkok.

Litzinger, T. A., Lee, S. H., Wise, J. C., \& Felder, R. M. (2007). A psychometric study of the Index of Learning Styles. Journal of Engineering Education, 96(4), 309-319.

Montgomery, S. M., \& Groat, L. N. (1998). Student learning styles and their implications for teaching.
CRLT Occasional Papers No. 10: The Center for Research on Learning and Teaching, the University of Michigan.

Neumann, R. (2001). Disciplinary differences and university teaching. Studies in Higher Education, 26(2), 135-146.

Ogot, M., \& Okudan, G. E. (2006). Systematic creativity methods in engineering education: A learning styles perspectives. Int. J. Engng Ed., 22 (3), 566-576.

Odle-Dusseau, H., Britt, T., \& Greene-Shortridge, T. (2012). Organizational work-family resources as predictors of job performance and attitudes: The process of work-family conflict and enrichment. Journal of Occupational Health Psychology, 17(1), 28-40.

Sinclair, A., \& Muffo, J. (2002). The use of Biglan categories in assessing general education courses. Educational Resources Information Center (ERIC). Paper presented at the Annual Forum for the Association for Institutional Research (42nd, Toronto, Ontario, Canada, June 2-5).

Taylor, S., \& Kluemper, D. (2012). Linking perceptions of rule stress and incivility to workplace aggression: The moderating role of personality. Journal of Occupational Health Psychology, 17(3), 316-329.

Van Dam, K., \& Van den Berg, P. (2004). Challenges for research in work and organizational psychology. Applied Psychology: An International Review, 53(4), 481-486.

Von Glinow, M. A., \& McShane (2008). Organizational Behavior (47th ed.). New York: McGrawHill Irwin. 